\title{
Marine Animals Protected by the IUCN Red Data List and CITES 1973 on Seagrass Ecosystems
}

\author{
Andreas Pramudianto ${ }^{1 *}$, Putut Suharso ${ }^{2}$, dan Nurul Hidayati ${ }^{3}$ \\ ${ }^{1}$ School of Environmental Science, University of Indonesia, Salemba Raya Street no. 4, Jakarta 10430 \\ Indonesia \\ ${ }^{2}$ Department of Library and Information Science, Diponegoro University, Prof. H. Soedarto SH street, \\ Semarang 50275 Indonesia \\ ${ }^{3}$ Postgraduated student Environmental Science Programme, School of Environmental Science, \\ University of Indonesia, Salemba Raya Street No. 4, Jakarta 10430, Indonesia
}

\begin{abstract}
Seagrass beds are important for providing ecological functions and ecosystem services, including its role as habitat for marine animals. In spite of their significance, they remain in decline. The change of seagrass beds will affect the associated animals. Some animals that live on seagrass beds protected by IUCN Red Data List and CITES 1973. Yet the data have not been properly recorded. The aim of this study was to find out the existence of marine animals protected by the Red Data List and CITES 1973 IUCN, especially in seagrass ecosystems in Indonesia. The method used in this research is mix method with desk study approach and presentation of data analyzed through review. The results of the study show that changes in seagrass ecosystems will affect the presence of migratory marine animals and those who live and settle in this ecosystem. The provisions in the IUCN Red Data List and CITES 1973 supported by national legislation in Indonesia will have significant impact on the protection of marine animals in seagrass beds.
\end{abstract}

\section{Introduction}

The condition of the marine ecosystem is currently experiencing significant threats. Climate change, pollution of plastic waste, oil pollution, is one of the reasons discussed today. While damage to ecosystems such as coral reefs, seagrass beds, and mangroves is also one of the problems faced today. As a result of development that is often uncontrolled, threats from the land to the coast and sea are increasing in intensity [1]. The amount of waste mainly plastic coming from the mainland also increases in the coast.

In Indonesia, which has a beach length of $99.093 \mathrm{~km}$, there are several areas that have seagrass ecosystems, including in Bali, Biak, Bintan, Wakatobi, and Lombok. Seagrass ecosystem as one of the ecosystems in the coast also experiences pressure mainly due to the increasing development process [2]. For example in Indonesia in the coastal area of Banten Bay, which experienced reclamation, reducing seagrass beds by about $30 \%$ used for luxury settlements, hospitality, and marine tourism. In the seagrass ecosystem, there are several types of marine animals that migrate and live and settle. The famous marine species and

\footnotetext{
*Corresponding author: uipram@gmail.com
} 
migrate to Indonesia and enter the seagrass ecosystem including green turtles (Chelonia midas). Meanwhile, the types of marine animals that live and settle in these ecosystem habitats include dugong (Dugong dugon). Generally, dugong depend on seagrass for food [3]. The existence of these marine animals are included in the IUCN category, namely critical, critical or vulnerable, threatened, almost threatened and other criteria [4]. In addition, the conditions will be different in various seagrass beds in Indonesia.

Threats to marine animals in the desert ecosystem are so large that they often affect the status of these marine animals in accordance with the IUCN category. Meanwhile, international law through CITES 1973 also regulates the trade in animals including marine animals in the seagrass ecosystem. These two instruments of international law are then followed up through national legislation. The problem that occurs is that research on marine animals that are protected in the seagrass ecosystem has not been properly recorded. This research will look at how international law will encourage national law to protect marine animals in seagrass beds.

\section{Materials and Methods}

The methodology used in this study uses a review approach [5]. Review of the IUCN Red Data List, CITES 1973 and national legislation, especially protection of marine animals and seagrass ecosystems [6]. In this review study data collection was conducted in relation to the state of seagrass beds in Indonesia, the ecosystems that live in their habitat, as well as the applicable laws and regulations which became a special study. The researcher summarizes and presents the author's thoughts about several sources of literature from the topics discussed [7]. In the literature review research related to seagrass beds, it is relevant, up-to-date, and adequate in addressing the problems in today's society[8].

A coastal region includes some combination of seagrass beds, coral reefs, and mangroves, hence there are important linkages between them. Seagrasses are aquatic angiosperms (flowering plant) that have rhizomes, true leaves, and roots that live and are submerged under the sea. Seagrass grows in large areas on the sea floor that are still exposed to sunlight and sufficient for their growth [9]. According to Dahuri et al. [10], there are 7 genera of tropical seagrass from 12 world seagrass genera, namely Enhalus, Thalasia, Halophila, Halodule, Cymodocea, Syringodium, and Thallasodendron. The presence of seagrass beds is spread throughout the world as shown in Figure.1.

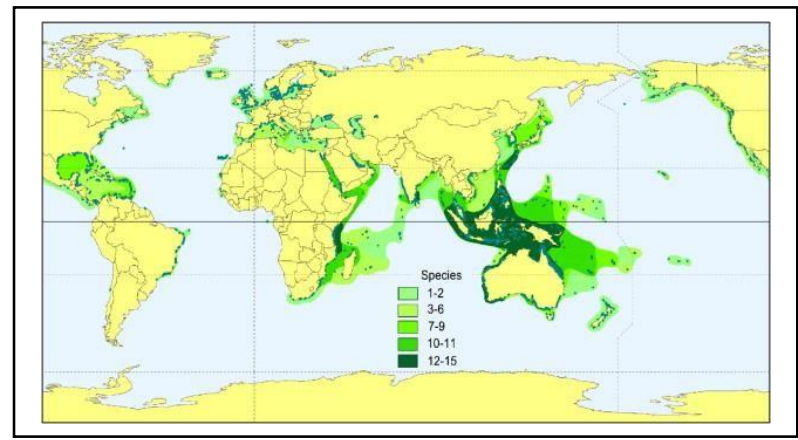

Fig. 1. Global Seagrass Distribution[11] 
Distribution of seagrass in Indonesia reaches 150.693 .16 ha in 22 locations around the country, including Java, Sumatera, Kalimantan, Sulawesi, Maluku, and Papua [12]. The distribution can be seen in Figure. 2.

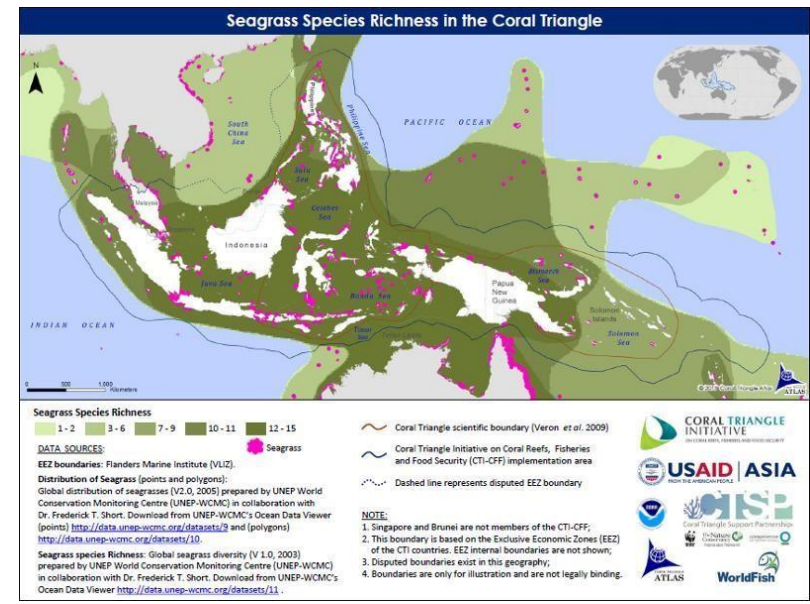

Source: http://ctatlas.reefbase.org/mapsofthemonth/Map14.aspx

Fig. 2. Seagrass beds in Indonesia in the framework of the Coral Reef Triangle

But the consequences of human activities such as reclamation, pollution of industrial waste, garbage disposal, pollution of agricultural waste, oil pollution, bombing and the effects of natural processes such as wind, currents, rain, waves etc. have led to reduced presence of seagrass beds.

Seagrass ecosystems have important roles as a source of primary productivity and a foraging and nursery ground for some marine biota [13]. There are four categories of animals that live in seagrass ecosystems [14], namely:

a. Biota that lives on leaves, examples: protozoa, nematodes, arthropoda, hydrozoa, actinia, gastropoda, nemertines, crustacean, echinodermata, hydromedusa, chepalopoda.

b. Biota attached to the stem and rhizome. For example polychaeta,amphipoda.

c. Species that move and live in the waters below the leaf canopy. For examplescaridae, siganidae, shrimp, squid. There is also Cheilinusundulatus.

d. Animals that live in and in sediments. For example benthos

According to AR Hughes et al. [15] 30\% species of seahorses that live in seagrass beds have been included in the IUCN Red Data List.

As an IUCN data the Red Data List is a list of the status of animals and plants which arecategorized into several statuses including Extinct (EX; Extinct); Extinct in the Wild (EW; Extinct in the Wild); Critically Endangered (CR; Critical), Endangered (EN; Critical or Threatened), Vulnerable (VU; Vulnerable), Near Threatened (NT; Near Threatened), Least Concern (LC; Low Risk), Data Deficient (DD; Information Less), and Not Evaluated (NE; Not Evaluated). First issued in 1984 and the IUCN Red Data Book is usually always evaluatedits status every five years. Currently, it is used based on the IUCN Red List version 3.1. Where as the Convention on International Trade in Endangered Species of Wildlife Flora and Fauna or the International Convention on the Trade of Species of Animals and Endangered Plants. This international agreement regulates the trade in endangered animals and plants.Signed on March 3, 1973 in the city of Washington, United States and fully valid on July 1,1975. Consisting of 25 Articles and 4 Attachments. Appendix I contains provisions regarding the total (total) prohibition of trade on species of flora and fauna that are classified 
as very rate. Annex II contains a variety of rare species but is still allowed to be traded with strict supervision. Appendix III applies to species which according to their country are rare and need special permission from the convention. Appendix IV is allowed to trade licenses for species that are not included in appendix I-III and documents and forms that must be completed with there quirements. In Indonesia, these two international rules have been enacted and some animals are also regulated in Government Regulation Number 7 of 1999 concerning Preservation of Plant and Animal Types and Government Regulation Number 8 of 1999 concerning Utilization of Plant and Wildlife Types and the Minister of Environment and Forestry Regulation Number P.20/MENLHK/SETJEN/KUM.1/6/2018 concerning the types of protected plants and animals. And through the regulation of the Minister of Maritime Affairs and Fisheries number 05/Permen-KP/2014 concerning SLIN (National Fish Logistics System) regulates fish supply [16] and maintains the sustainability of fisheries ecosystems in Indonesia. Understanding the community about marine ecosystems can be done with information literacy programs for coastal communities through learning facilities owned by coastal libraries [17-19].

This research will only identify the status of animals and the list of animals listed in the appendix as well as national legislation.

\section{Results and Discussions}

There are various types of marine animals that live in this ecosystem, one of them is Dugong dugon(dugong, sea cows). These animals belong to the vulnerable category on the IUCN Red Data List. In CITES 1973 included Appendix II which is currently being proposed to enter Appendix I. This means that the dugong is still allowed to be traded but with very strict supervision.

In Indonesia, dugongs are included as protected animals based on the attachment of Minister of Environment and Forestry Regulation No. P. 20/KLHK/SETJEN/KUM.1/6/2018. In other countries, there are also types of dugongs (Trichechus manatus) that live in seagrass ecosystems in the waters of the State of Florida, United States which fall into the category of Vulnerable C1 ver 3.1 (prone) IUCN Red Data List. Other types of animals such as eelgrass (eel) type of Zostera japonica that live in the seagrass ecosystem in Japan are included in the category of IASTN Least Concern Red Data List which means that these marine animals are still found in several places in the seagrass beds ecosystem. Migrant species can also be found in this ecosystem such as Chelonia midasor green turtles. In the IUCN Red Data List, this turtle includes Endangered/EN status (threatened). As marine animals that migrate far away, these animals are included in Appendix I CITES 1973 which means that they are prohibited from being traded at all.

Besides sea turtles, there are also seahorses including dwarf seahorse (Hippocampus zosterae) which are categorized as Least Concern / Low Risk by the IUCN Red Data List. Seahorses include the types of marine animals traded and regulated in Appendix II CITES 1973 which was the 12th COP decision in Santiago, Chile on 3-15 November 2002. This can be interpreted as allowed to be exported with a certificate from the management authority. In Indonesia there are 9 types of seahorses, Hippocampus barbouri, H. comes, H. histrix, H. kelloggi, $H$. horse, $H$. barbiganti, $H$. trimaculatus, $H$. spinosissimus, and $H$. denise. In the IUCN Red Data List for zebra-snout seahorse (H. barbouri), tiger tailed seahorse (H. comes), spotted seahorse $(H$. kuda), and flat-faced seahorse $(H$. trimaculatus) are included in the Vurnerable / V category (susceptible) and 4 other species in the category data deficient (DD) or not enough data available, namely: hedgehog seahorse (Hippocampus spinosissimus), spine seahorse (H. histrix), great seahorse (H.kelloggi),

Bargibant's seahorse (H. bargibanti), and Denise's pygmy seahorse (H. denise) [18]. 
Trading and utilization of seahorses is usually used as medicine. Provisions on the export of seahorses are regulated in Regulation of the Minister of Trade No.50/M-DAG/PER/9/2013 concerning Provisions on the Export of Natural Plants and Wildlife that are Not Protected by Law and Included in the CITES List. There are five types of seahorses which are included in the export list including $H$. barbouri, H. comes, H. histrix, H. kelloggi, H. kuda, and $H$. spinosissimus. While the trade quota is regulated through the Decree of the Director General of Forest Protection and Nature Conservation No. SK.51/IV-SET / 2015 concerning the Quota for the Harvesting of Natural Plants and Arrest of Wild Animals for the Period of 2015, explained that the types of seahorses that may be traded for export purposes are only $H$. barbouriwith a catch of 5000 and an export quota of 4500 from fishing location in South Sulawesi Province and exported in life form (not dry/dried form or powder form). Whereas fish species such as caribbean rainbow parrotfish and Scarusguacamaiawhich can be found in seagrass ecosystems in the Karabia area by the IUCN Red Data List are included in Near Threatened/NT or Nearly Threatened. This type of Cheilinusundulatusis also found in coral reef ecosystems, including in the Endangered/EN category (IUCN Red DataList).

In Indonesia, there is a fish called napoleon wrasse (Cheilinusundulatus). This fish is included in CITES 1973 appendix II. Its regulation is regulated in various laws and regulations such as the Minister of Agriculture Decree No. 375/Kpts/IK.250/95 concerning Napoleon Wrasse Fishing (Cheilinusundulatus) and Decree of the Director General of Fisheries No. HK.330/Dj.8259/95 concerning Size, Location, Procedures for Catching Napoleon Wrasse Fish. Since the existence of the Ministry of Maritime Affairs and Fisheries, it is regulated through the Regulation of the Minister of Marine and Fisheries No. PER.03/MEN/ 2010 concerning the Procedure for Determination of the Status of Fish Type Protection which is specifically for Napoleon fish regulated by the Decree of the Minister of Marine and Fisheries Number 37 of 2013 concerning Status Determination Limited Napoleon Fish Protection. There are still many marine animals that live in seagrass beds that have not been identified.

The existence of seagrass ecosystems is very important for the lives of marine animals that depend on this ecosystem. Therefore if this ecosystem is polluted or damaged, then the life of marine animals will be threatened and even extinct. Provisions in international law and national law have sought to protect this ecosystem, including marine animals in this ecosystem. The types of plants in this ecosystem are partly protected through the 1982 United Nations Convention on the Law (UNCLOS), the 1992 United Nations Convention on Biological Diversity (UNCBD), UNEP Regional Sea's Convention, CITES 1973 and several other international agreements. Meanwhile, the existing marine animals are also protected by many other international agreements. However, this threat to marine ecosystems and animals still exists. Marine animals that are threatened with extinction will be very detrimental to the life of the ecosystem itself and to human life. For human life, some marine animals can be used for several things such as food, decoration, hobbies and so on. Therefore, marine wildlife trade is also carried out in many countries, it is still limited through the existence of CITES 1973. With international law such as CITES 1973 and national law such as Government Regulation (PP) No. 7 of 1999, of course, it will have an impact on the ecosystem of seagrass beds and marine animals. However, these regulations actually still have gaps and weaknesses, especially the nature of the regulations themselves. It is true, the characteristics of a regulation are not easily changed quickly, and it takes a long time to change it. However, in the regulatory framework related to animal species, it seems that the characteristics will differ. Changes can be made through existing attachments, although research that is sometimes long enough isneeded.

Dynamic environmental conditions such as the existence of an ecosystem and animals that change rapidly are often not balanced with existing regulations [20]. As an example of the diminishing condition of seahorses, it must be balanced with regulations that limit or even 
prohibit the capture or utilization of seahorses. In reality, regulations cannot reach quickly to limit the use of seahorses. Research is needed first so that the regulations will adjust to the results of research. Even though conditions in nature, seahorses can become extinct. Indications of research are needed to determine the status of these animals. Thus between reality in nature in the form of information, research carried out, and existing regulations and changes or planning of existing regulations are very close. Collaboration between parties is needed between the community as information providers, researchers, and the government so that the protection of ecosystems and animals can have a positive impact on sustainable development.

\section{Conclusion}

Seagrass beds are actually very susceptible to change due to the increasingly intensive development process. Pollution and damage to seagrass beds will cause a reduction in even the extinction of marine animals in this ecosystem. Because of that, the presence of marine animals can be identified through the IUCN Red Data List and trade and utilization are regulated through international law, especially international agreements such as CITES 1973. In Indonesia, knowing some marine animals in the seagrass ecosystem requires legal protection. But there are also marine animals besides being protected also traded with certain quota. In addition to the arrangement through the IUCN Red Data List, CITES 1973 and other international agreements, there are also national legislation that is expected to control and manage so as to reduce, limit and even prohibit the trade of marine animals for certain types of marine animals. It is expected that the results of this study can help decision makers to act within the framework of protecting the ecosystem of seagrass beds and marine animals so that they do not experience extinction.

\section{References}

1. U. Tangke. J. Ilm. Agribisnis dan Perikan 3 (2010)

2. M. Hutomo and M. H. Azkab. Oseana 12, 1 (1987)

3. J. K. Sheppard, H. Marsh, R. E. Jones, and I. R. Lawler. Mar. Mammal Sci 26, 4 (2010)

4. I. G. Domiciano, C. Domit, and A. P. F. R. L. Bracarense. Semin. Agrar 38, 5 (2017)

5. C. Lamont, Research Methods in International Relations. (Los Angeles, Sage Publication, 2015)

6. R. G. Coles and M. D. Fortes, Protecting seagrass: approaches and methods, in global seagrass research methods, (Amsterdam, Elsevier, 2003)

7. A. Groso, A. Ouedraogo, and T. Meyer. J. Risk Res 15, 2 (2012)

8. G. A. Bowen. Qual. Res. J 9, 2 (2009)

9. R. Hartati, A. Djunaedi, Mujiyanto, and Hariyadi,. Ilmu Kelaut 17, 4 (2012)

10. R. Dahuri and I. M. Dutton, Integrated coastal and ocean management enters a new era in Indonesia (2000)

11. P. L. Reynolds. Seagrass and seagrass beds (2013)

12. U. E. Hernawan et al., Status padang lamun indonesia 2017. (Jakarta, Pusat Penelitian Oseanografi, LIPI, 2017)

13. M. Kawaroe, A. H. Nugraha, Juraij, and I. A. Tasabaramo. J. Biol. Divers 17, 2 (2016)

14. R. C. Phillips and N. a. Milchakova. Морський Екологічний Журнал 5 (2003) 
15. A. R. Hughes, S. L. Williams, C. M. Duarte, K. L. Heck, and M. Waycott. Front. Ecol. Environ 7, 5 (2009)

16. M. Azhar, S. Suhartoyo, P. Suharso, V. E. Herawati, and N. Trihastuti. E3S Web Conf. SCiFiMaS 47 (2018)

17. P. Suharso and S. Sarbini. E3S Web Conf. SCiFiMaS 47 (2018)

18. P. Suharso, B. Sudardi, S. T. Widodo, and S. K. Habsari. IOP Conf. Ser. Earth Environ. Sci 116, 1 (2018)

19. P. Suharso, B. Sudardi, S. T. Widodo, and S. K. Habsari. E3S Web Conf. SCiFiMaS 47, (2018)

20. F. Jensen, H. Frost, and J. Abildtrup. Mar. Policy 81 (2017) 